\title{
ОЦІНКА РІВНЯ ЗНАНЬ, ПРИХИЛЬНОСТІ ТА ПРАКТИКИ МЕДИЧНИХ ПРАЦІВНИКІВ ЩОДО РОБОТИ ІЗ СУДИННИМИ КАТЕТЕРАМИ ТА ЗАПОБІГАННЯ ІНФЕКЦІЙНИМ УСКЛАДНЕННЯМ КАТЕТЕРИЗАЦІЇ СУДИН
}

\author{
Харківський національний медичний університет
}

Мета роботи - вивчити рівень знань, прихильності та практики медичних працівників (МП) щодо роботи із судинними катетерами (СК) та запобігання інорекційним ускладненням процедури катетеризації.

Пацієнти і методи. Проведено поперечне епідеміологічне дослідження серед 123 МП закладів охорони здоров'я України протягом вересня-листопада 2019 р. та січня 2020 р. з використанням авторського опитувальника. Опитувальник складався з трьох блоків $і$ містив 48 питань. Статистична обробка даних проводилась з використанням методів описової статистики за допомогою програм Microsoft Excel 2007 ma Epi Info ${ }^{\mathrm{TM}}$ for Windows version 7.2. Аналіз номінативних величин проводився з використанням критерію Пірсона $\chi^{2}$. Достовірно значущими вважалися відмінності при $P<0,05$.

Результати досліджень та їх обговорення. Більшість респондентів (78,3 \%) вказала на необхідність отримувати більше інфрормації про можливі ускладнення катетеризації судин, а 79,3 \% опитаних потребують додаткової інформації щодо інфекційного контролю та профрілактики інфрекцій, пов'язаних 3 катетеризацією судин. Виявлено статистично достовірний зв'язок між потребою отримувати додаткову інорормацію про ускладнення катетеризації судин і посадою, яку займає респондент (молодший спеціаліст з медичною освітою): $X^{2}=7,9758, p=0,004741$.

Виявлено недостатню обізнаність МП щодо груп і фракторів ризику інфекційних ускладнень катетеризації судин. Майже третина опитаних (31,1 \%) вважала, що медичний персонал має незначний вплив на рівень інфекційних ускладнень катетеризації судин. В середньому тільки 33,4 \% респондентів знали, що рутинну заміну центральних венозних катетерів (ЦВК), перифрерично імплантованих ЦВК і катетерів для гемодіалізу для профрілактики катетер-асоційованих інфрекцій кровоплину застосовувати не доцільно. 99,2 \% МП вважали, що перед будь-якою маніпуляцією із СК та після неї необхідно обов'язково проводити гігієнічну обробку рук із застосовуванням води з милом та спиртового антисептика. У рутинній практиці завжди користувались рукавичками під час маніпуляцій із СК 97,5 \% респондентів. 11,6 \% МП допускає, що використання рукавичок може замінити гігієнічну обробку рук при роботі із СК.

Встановлено, що найчастіше МП нехтували використанням рукавичок при роботі із СК через недостатню забезпеченість рукавичками (29,7\%). Чверть респондентів (25,0 \%) замінювала рукавички процедурою гігієнічної обробки рук. Через виникнення алергічних реакцій або контактного дерматиту в результаті застосування рукавичок від їх використання відмовлялось 20,3 \% опитаних.

Висновки. Виявлено недостатній рівень знань, прихильності та практики МП з питань епідеміології, інфрекційного контролю та профрілактики інфрекційних ускладнень катетеризації судин.

Ключові слова: поперечне дослідження, катетерасоційовані інфекції кровоплину, інфекційний контроль, гігієна рук.

За даними Європейського центру з контролю та профрілактики захворювань (ECDC), у 2017 р. інорекції кровоплину займали друге місце у структурі захворюваності пацієнтів відділень інтенсивної терапії Європейського регіону на інфекції, що пов'язані з наданням медичної допомоги (ІПНМД). Більш ніж третина зареєстрованих інорекцій кровоплину (37 \%) були пов'язані 3 використанням судинних катетерів (СК) [1]. Оскільки катетеризація судин широко застосовується в медичній практиці для вирішення цілої низки діагностичних і лікувальних завдань, питання професійної підготовки медичних працівників щодо правил роботи із СК та профрілактики інфекційних ускладнень є вкрай актуальними. Дослідження зарубіжних авторів показали, що частина МП мала недостатній та низький рівень знань про кате- 
тер-асоційовані інфекції кровоплину (КАІК), а відсоток неправильних відповідей коливався від 27,1 до 96 [2-4]. Оскільки в Україні проблема ІПНМД і, зокрема, інфекційних ускладнень катетеризації судин (в тому числі KAIK) досі не отримала належної уваги, метою роботи стало вивчення рівня знань, прихильності та практики МП щодо роботи із СК та запобігання інфекційним ускладненням процедури катетеризації.

\section{Пацієнти і методи}

Проведено поперечне епідеміологічне дослідження серед 123 МП закладів охорони здоров'я України протягом вересня-листопада 2019 р. та січня 2020 р. $з$ використанням авторського опитувальника «Використання внутрішньосудинних катетерів у клінічній практиці» [5].

При виборі учасників опитування перевага надавалася тим МП, які в ході своєї практичної діяльності часто працюють із СК (беруть безпосередню участь у процедурі катетеризації або у догляді за вказаними девайсами).

Участь в опитуванні була анонімною, добровільною та безоплатною. 3 метою дотримання принципів біоетики та біобезпеки всім потенційним респондентам попередньо було надано Інформаційний лист учасника опитування, в якому повідомлялось, що інорормація про їх участь у дослідженні залишається суворо конфіденційною, а узагальнені результати опитування можуть бути опубліковані, обговорюватись дослідниками, а також представниками уповноважених державних структур із збереженням коноріденційності особистих даних респондентів. Усі респонденти, які погодилися взяти участь у дослідженні, попередньо підписали Інорормовану згоду на участь в опитуванні.

Опитувальник для дослідження розроблено з використанням інорормаційного матеріалу керівництв Центрів 3 контролю та профрілактики захворювань у Сполучених Штатах Америки (CDC), Американської асоціації анестезіологів (ASA) та Міжнародної асоціації інсрекційних хвороб (ISID) щодо питань забезпечення судинного доступу і профрілактики КАІК, та наказу Міністерства охорони здоров'я України від 21.09.2010 р. № 798 «Про затвердження методичних рекомендацій «Хірургічна та гігієнічна обробка рук медичного персоналу»». Опитувальник складався з трьох блоків і загалом містив 48 питань (42 основних і 6 додаткових).

Перший блок включав загальні питання, пов'язані 3 визначенням соціально-демограсрічних (вік, стать) і професійних характеристик респондентів (посада, стаж роботи, кваліфікаційна категорія, відділення, де працює МП, та деякі аспекти практичної діяльності).

У другому блоці МП мали:

- дати самооцінку власним знанням і визначити необхідність в отриманні додаткової інфрормації про можливі ускладнення, спричинені катетеризацією судин, іноеекційний контроль та профрілактику КАІК;
- вказати джерела інформації про КАІК;

- визначити провідні групи та фрактори ризику інфекцій, пов'язаних з катетеризацією судин;

- оцінити вплив медичного персоналу на виникнення інфекційних ускладнень, пов'язаних з катетеризацією судин.

Для перевірки рівня знань щодо питань постановки та догляду за СК, а також просрілактики інфекційних ускладнень катетеризації судин, респондентам було запропоновано погодитись або спростувати ряд тверджень. Питання містили 5 можливих варіантів відповідей: «Цілком згоден», «Згоден», «Важко відповісти», «Не згоден», «Цілком не згоден».

Третій блок включав питання для визначення знань, прихильності та практики виконання обробки рук і використання медичних рукавичок у процесі своєї практичної діяльності та при роботі із СК.

Статистична обробка даних проводилася з використанням методів описової статистики за допомогою програм Microsoft Excel 2007 та Epi Info ${ }^{\text {TM }}$ for Windows version 7.2. Аналіз номінативних величин проводився з використанням критерію Пірсона $\chi^{2}$. Достовірно значущими вважалися відмінності при $\mathrm{P}<0,05$.

\section{Результати досліджень та їх обговорення}

До дослідження було залучено МП (24 чоловіків та 99 жінок) у віці від 19 до 70 років. Більшість опитаних - це молодші спеціалісти з медичною освітою (97 сестер медичних, 1 фельдшер-лаборант та 1 рентген-лаборант). Майже половина респондентів ( $\mathrm{n=60}$ - 48,8 \%) мала вищу кваліфікаційну категорію. Стаж роботи респондентів у медицині коливався від 4 міс. до 50 років. У таблиці 1 представлено детальну інсрормацію про соціально-демографрічні та професійні характеристики опитаних.

Зі 105 респондентів, які підтвердили, що їх практична діяльність часто пов'язана із СК, 104 особи вказали тип катетера, з яким вони переважно працюють. Виявилось, що половина МП (n=52 - 50,0 \%) зазвичай працює з периферичними венозними катетерами типу «венфрлон» або «метелик». Трохи менше респондентів ( $n=50$ - 48,1 \%) вказало, що їх професійна діяльність пов'язана однаковою мірою як з перифреричними венозними катетерами, так і з центральними венозними катетерами (ЦВК). Тільки 2 особи (1,9 \%) вказали, що здебільшого працюють 3 ЦВК.

Між тим, лише 65,0 \% (n=67) респондентів з числа тих, хто часто працює із СК та дав відповідь на зазначене питання ( $\left.\mathrm{n}_{\text {валідне }}=103\right)$, за час своєї професійної діяльності коли-небудь проходили курси, тренінги або заняття, на яких їм роз'яснювали показання до катетеризації судин та навчали належній техніці виконання 
Соціально-демографрічні та професійні характеристики респондентів

\begin{tabular}{|c|c|c|}
\hline \multirow{2}{*}{ Стать (n=123) } & чоловіча & $24(19,5 \%)$ \\
\hline & жіноча & $99(80,5 \%)$ \\
\hline \multirow{3}{*}{ Вік у роках $(\mathrm{n}=118)$} & середнє стандартне відхилення & $37,8 \pm 13,3$ \\
\hline & медіана & 37,0 \\
\hline & мода & 22 \\
\hline \multirow{2}{*}{ Посада (n=123) } & лікар & $24(19,5 \%)$ \\
\hline & молодший спеціаліст з медичною освітою & $99(80,5 \%)$ \\
\hline \multirow{4}{*}{ Кваліфрікаційна категорія (n=123) } & вища & $60(48,8 \%)$ \\
\hline & перша & $10(8,1 \%)$ \\
\hline & друга & $17(13,8 \%)$ \\
\hline & без категорії & $36(29,3 \%)$ \\
\hline \multirow{3}{*}{ Стаж роботи в медицині у роках (n=123) } & середнє стандартне відхилення & $17,5 \pm 12,6$ \\
\hline & медіана & 17,0 \\
\hline & мода & 2 \\
\hline \multirow{4}{*}{$\begin{array}{l}\text { Профріль відділення, в якому працював респондент } \\
(\mathrm{n}=123)\end{array}$} & реанімація, інтенсивна терапія & $46(37,4 \%)$ \\
\hline & хірургічний профріль & $61(49,6 \%)$ \\
\hline & терапевтичний профіль & $15(12,2 \%)$ \\
\hline & діагностичний профріль & $1(0,8 \%)$ \\
\hline $\begin{array}{l}\text { Часта робота з внутрішньосудинними катетерами } \\
\text { в практичній діяльності }(\mathrm{n}=123)\end{array}$ & так & $105(85,4 \%)$ \\
\hline Навчання щодо питань катетеризації судин (n=121) & так & $71(58,7 \%)$ \\
\hline $\begin{array}{l}\text { Випадки у практичній діяльності, пов'язані з інфек- } \\
\text { ційними ускладненнями, які викликані катетериза- } \\
\text { цією судин ( } \mathrm{n}=123)\end{array}$ & так & $96(78,0 \%)$ \\
\hline
\end{tabular}

процедур з установки і догляду за СК. Частка МП, які проходили подібне навчання протягом останнього року, була ще менше та складала 31,1 \% $(n=32)$.

Значна частина опитаних ( $\mathrm{n}=96$ - 78,0 \%) вказала, що за час своєї роботи стикалася з пацієнтами з інфекційними ускладненнями, сричиненими катетеризацією судин. Причому в основному це були локальні фрорми інфекції (n=87 - 90,6 \%). У 6,3 \% випадків (n=6) МП вказали, що у практиці бачать локальні та генералізовані фрорми з однаковою частотою; інші 3,1 \% респондентів $(\mathrm{n}=3)$ вказали винятково на генералізовану інфрекцію.

У цілому, незважаючи на те, що більшість учасників опитування бачила пацієнтів з інфекційними ускладненнями катетеризації судин, це здебільшого (у 68,9% випадків) траплялося рідко.

Аналіз питань другого блоку показав, що значна частина респондентів ( $\mathrm{n}=943 \mathrm{n}_{\text {валідне }}=120$ - 78,3 \%) вказала на необхідність отримувати більше інорормації про можливі ускладнення, спричинені катетеризацією судин. Крім того, 79,3 \% опитаних (n=96 $\left.3 \mathrm{n}_{\text {валідне }}=121\right)$ відчувають потребу в додатковій інформації з питань інфрекційного контролю та профрілактики інфекцій, пов'язаних 3 катетеризацією судин. Виявлено статистично достовірний зв'язок між потребою отримувати додаткову інформацію про ускладнення катетеризації судин і посадою, яку займає респондент (молодший спеціаліст з медичною освітою): $\chi^{2}=7,9758, p=0,004741$.

У ході дослідження було з'ясовано, що для більшості опитаних МП (n=64 - 52,5 \%) основним джерелом інформації про КАІК є їх колеги. Третина респондентів (n=48 - 39,3 \%) користується локальними протоколами лікувального закладу, в якому працює. Майже чверть опитаних (n=27 - 22,1 \%) посилалась на національні рекомендації та протоколи МОЗ України, хоча подібні документи досі не розроблено та не впроваджено у медичну діяльність на державному рівні. Звісно, наразі $€$ нормативно-правові документи (наприклад, накази 
МО3 України від 10.05.2007 р. № 234, від 04.04.2008 р. № 181, від 04.04.2012 р. № 236), що регламентують питання внутрішньолікарняних інорекцій, зокрема післяопераційних інсрекцій в галузі хірургічного втручання, але інформації у них недостатньо й вона потребує змін і доповнень. Дев'ять респондентів (7,4 \%) зазначило, що не володіє інорормацією про КАІК. На малюнку 1 графрічно представлено детальний аналіз джерел інфрормації про КАІК для респондентів.

Для оцінки рівня інорормованості респондентів про категорії пацієнтів, які мають високий ризик виникнення інфекційних ускладнень, пов'язаних 3 катетеризацією судин, МП було запропоновано обрати одну або декілька відповідей із зазначеного списку: «пацієнти відділень реанімації та інтенсивної терапії», «пацієнти неврологічних відділень», «пацієнтки пологових відділень», «пацієнти опікових відділень», «пацієнти відділень онкогематології», «пацієнти, які отримують гемодіаліз», «пацієнти інфекційних відділень», «пацієнти терапевтичних відділень», усі вищезазначені категорії», «жодна з вищезазначених категорій». Останні два варіанти відповідей було включено навмисно, щоб заплутати тих респондентів, які не володіють цією інформацією або невпевнені у своїх знаннях.

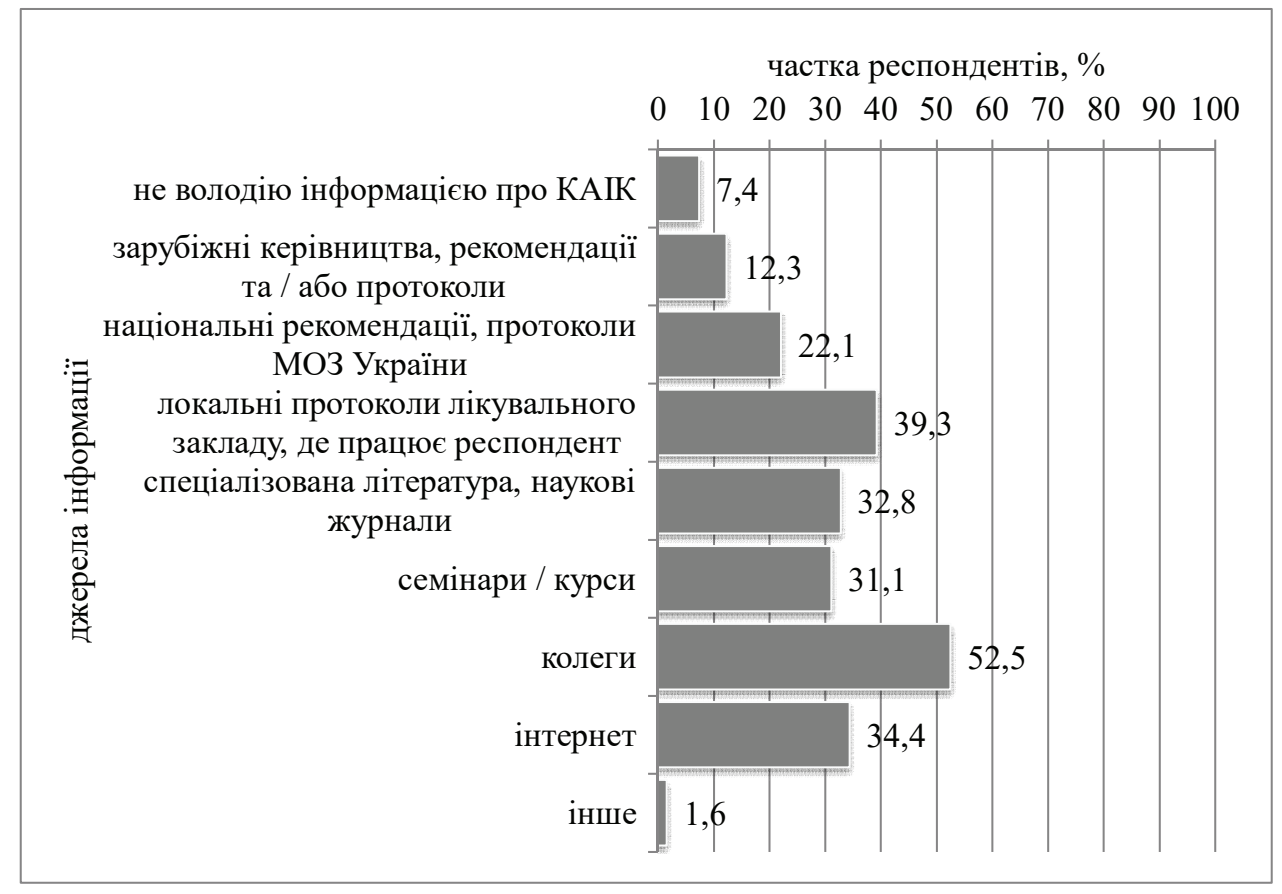

Мал. 1. Джерела інформації про КАІК для респондентів (n=122).

При аналізі даних встановлено, що МП мають недостатній рівень знань про групи ризику виникнення інфекцій, пов'язаних з катетеризацією судин. Значна частина опитаних (n=52 - 43,0 \%) обрала всі категорії пацієнтів, що неправильно. Майже стільки ж респондентів ( $\mathrm{n}=51$ - 42,1 \%) віднесло до групи ризику інфекційних ускладнень катетеризації судин пацієнтів відділень реанімації та інтенсивної терапії. Далі за частотою обраних відповідей слідують інфекційні хворі; пацієнти опікових відділень; особи, які отримують гемодіаліз; онкогематологічні хворі; неврологічні хворі; особи, які перебувають на лікуванні в терапевтичних відділеннях, та пацієнтки пологових відділень (мал. 2).

Для визначення рівня обізнаності МП про чинники ризику виникнення інорекційних ускладнень катетериза- ції судин можливі фрактори було згруповано у три категорії: 1) фрактори ризику, пов'язані із СК (матеріал СК, тривалість катетеризації, число з'єднань/портів СК, анатомічна ділянка катетеризації, тип фріксуючого матеріалу, розмір СК); 2) фрактори ризику, пов'язані з особливостями лікувального процесу (застосування парентерального харчування у пацієнта, недостатня квалісрікація медичного персоналу, тривалість госпіталізації до початку катетеризації, порушення правил асептики при постановці та догляду за СК, часті медичні маніпуляції із СК) та 3) срактори ризику, пов'язані з характеристиками пацієнтів і станом їх здоров'я (вік, стать, тяжкість стану, ожиріння, цукровий діабет, наявність вогнищ хронічної інфекції, імунодефіцит). 


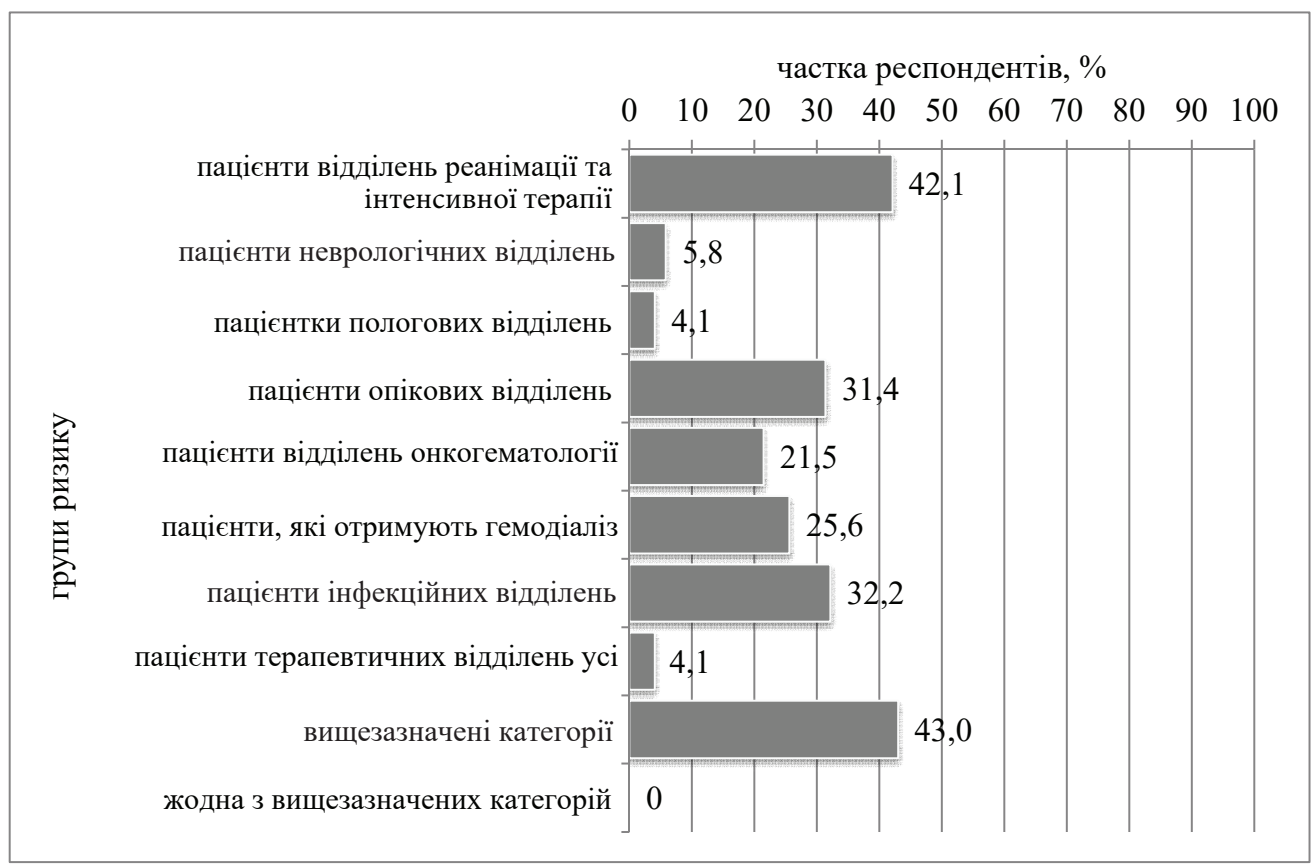

Мал. 2. Розподіл відповідей респондентів ( $\mathrm{n=121)}$ щодо груп ризику інфекційних ускладнень, пов'язаних $з$ катетеризацією судин.

При аналізі відповідей респондентів щодо фракторів ризику, пов'язаних із СК, встановлено, що значна частина опитаних (n=78 - 63,4 \%) здебільшого пов'язує вірогідність виникнення інфекційних ускладнень 3 тривалістю катетеризації. Майже вдвічі менше респондентів (n=37 - 30,1 \%) вважало, що матеріал, з якого ви- готовлено СК, впливає на частоту виникнення інфекційних ускладнень катетеризації. Така ж кількість респондентів (n=37 - 30,1 \%) обрала всі зазначені в переліку потенційні фактори ризику. Наочний розподіл відповідей респондентів щодо інших ймовірних фракторів ризику представлено на малюнку 3.

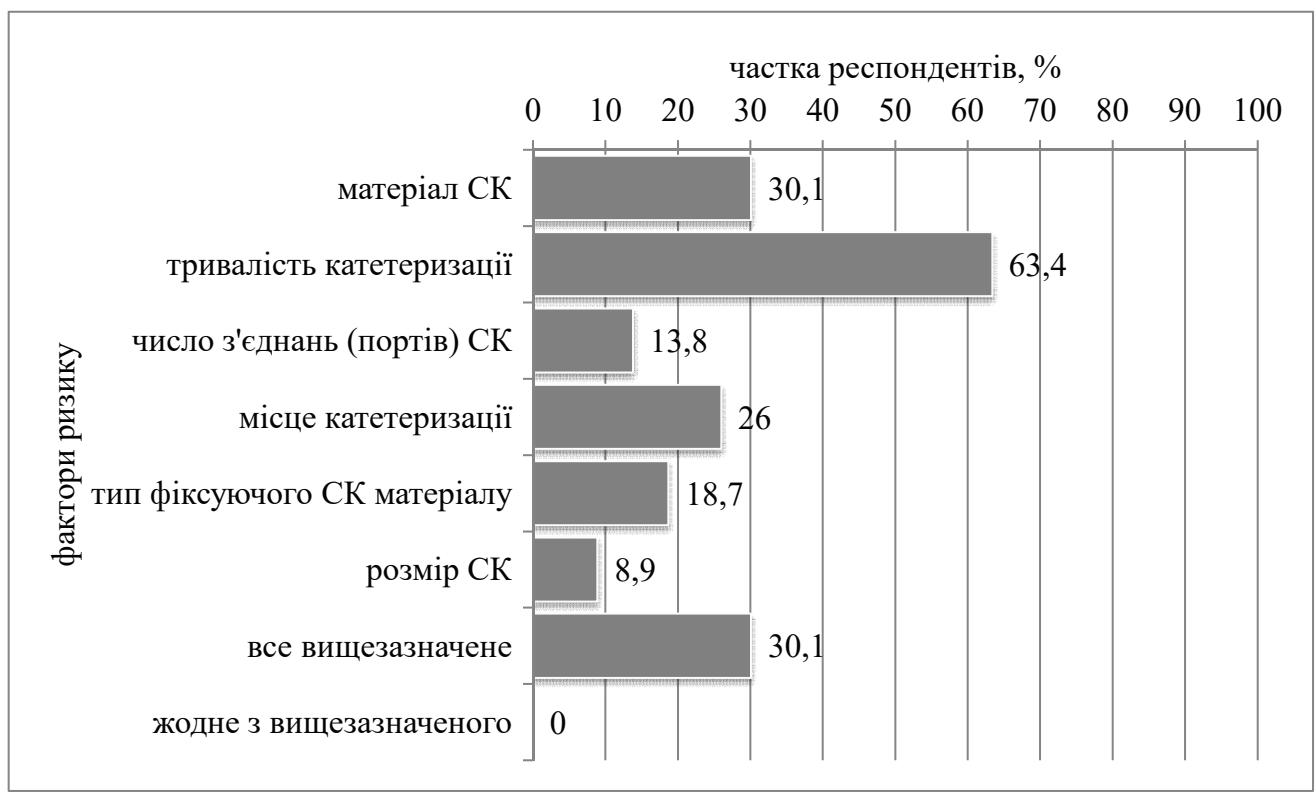

Мал. 3. Розподіл відповідей МП (n=123) щодо фракторів ризику інфекційних ускладнень катетеризації судин, пов'язаних із CK. 
При аналізі відповідей респондентів $(\mathrm{n}=122)$ щодо фракторів ризику інфекційних ускладнень катетеризації судин, пов'язаних з особливостями лікувального процесу, встановлено, що більшість МП (n=107 - 87,7 \%) розуміє необхідність у дотриманні правил асептики при постановці та догляді за СК для запобігання інорікуванню. При цьому тільки половина респондентів погодилась, що недостатня кваліфікація медичного персоналу ( $\mathrm{n}=62-50,8 \%)$ та часті медичні маніпуляції із СК (n=58 - 47,5 \%) можуть стати причиною виникнення інфекційних ускладнень процедури катетеризації. Незначна кількість опитаних пов'язують ризик виникнення інфекційних ускладнень із тривалістю перебування пацієнта в стаціонарі, яке передувало процедурі катетеризації (n=15 - 12,3 \%), та застосуванням парентерального харчування ( $n=5-4,1 \%)$.

До фракторів ризику інфекційних ускладнень катетеризації судин, пов'язаних із демографрічними характеристиками пацієнтів і станом їх здоров'я, майже дві третини респондентів віднесли наявність вогнищ хронічної інфекції в організмі пацієнта (n=78 - 64,5 \%) та цукровий діабет ( $\mathrm{n}=74-61,2 \%)$. Менше ніж чверть МП $(n=22-18,2$ \%) вказали, що новонароджені та люди похилого віку мають вищий ризик виникнення таких ускладнень порівняно з іншими віковими групами пацієнтів. Детальна інфрормація представлена на малюнку 4.

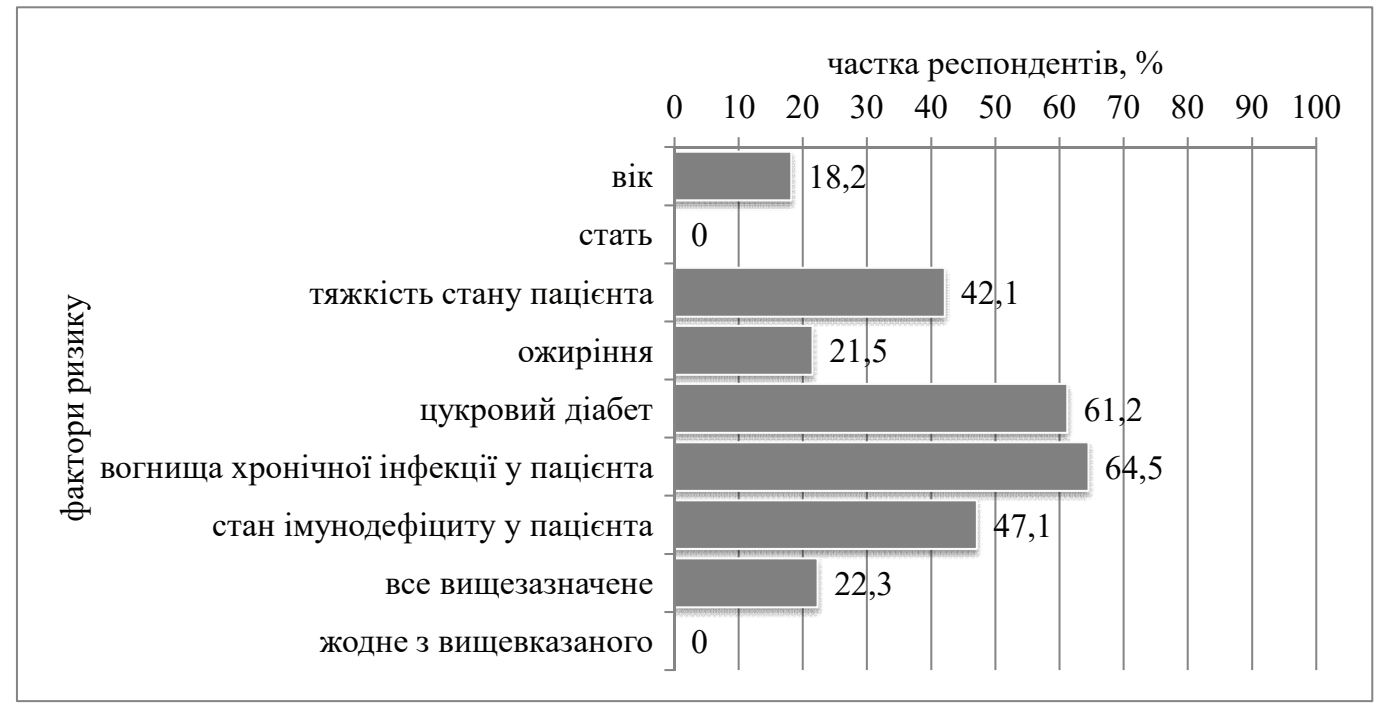

Мал. 4. Розподіл відповідей МП (n=121) щодо фракторів ризику інфекційних ускладнень катетеризації судин, пов'язаних з демографрічними характеристиками пацієнтів і станом їх здоров'я.

Респондентам було запропоновано оцінити за 10-бальною шкалою роль МП у виникненні інфекцій, пов'язаних з катетеризацією судин. Оцінка в 1 бал означала, що медичний персонал майже не впливає на рівень інфекційних ускладнень катетеризації судин, а оцінка в 10 балів, навпаки, свідчила про суттєвий вплив медиків на частоту виникнення таких ускладнень. Для спрощення аналізу отримані дані було проранжовано: результат в 1-2 бали оцінено як дуже низький вплив; 3-4 бали - низький вплив; 5-6 балів - помірний вплив; 7-8 балів - високий вплив; 9-10 балів - дуже високий вплив. Зі 122 осіб, які дали відповідь, четверта частина зазначила ( $n=30$ - 24,6 \%), що медичний персонал має помірний вплив на рівень інфекційних ускладнень катетеризації судин. Дещо менше респондентів ( $\mathrm{n}=28$ 23,0 \% та $n=26$ - 21,3 \%) вказали відповідно про високий та дуже високий вплив МП на виникнення інфекцій, пов'язаних 3 катетеризацією судин. Між тим, 17,2 \% (n=21) та 13,9 \% (n=17) респондентів вважали, що МП мають відповідно низький та дуже низький вплив на рівень інсекційних ускладнень катетеризації судин. Зауважимо, що 89,5 \% респондентів з числа тих, хто дав оцінку в 1-4 бали, у процесі своєї практичної діяльності часто працюють із СК. Тобто майже третина ( $\mathrm{n}=38$ 31,1 \%) всіх опитаних неправильно оцінює власну роль у патогенезі KАІК, коли недостатня кваліфрікація медичного персоналу, часті медичні маніпуляції із СК, порушення правил асептики при постановці та догляді за СК, призводять до мікробної колонізації СК, що, своєю чергою, може стати причиною виникнення як локальних, так і генералізованих фрорм інфекції. Така недооцінка ролі медичного персоналу у розвитку інорекційних ускладнень катетеризації судин, вірогідно, є результатом недостатнього рівня знань респондентів з питань використання та догляду за СК, про що безперечно свідчать їх наступні відповіді на теоретичні запитання. 


\section{ОРИГІНАЛЬНІ ДОСЛІДЖЕННЯ}

Переважна частина респондентів знала, що при постановці СК та догляді за ним необхідно дотримуватися правил асептики (n=119 - 96,7%), а пов'язку, яка фріксує катетер, необхідно замінити, якщо вона забруднилась (n=117 - 95,1 \%), ослабла (n=114 - 92,7 \%) або стала вологою (n=112 - 91,1 \%). Між тим, 72,1 \% опитаних (n=88 з $\left.\mathrm{n}_{\text {валідне }}=122\right)$ не володіли правильною інформацією щодо термінів заміни прозорих пов'язок для фріксації короткострокових ЦВК. Тільки половина респондентів (n=67 $3 \mathrm{n}_{\text {валідне }}=121-55,4 \%$ ) погодилась, що для обробки шкіри перед введенням ЦВК, периферичного артеріального катетера та під час заміни пов'язки доцільно використовувати спиртовий розчин хлоргексидину у концентрації більш ніж 0,5 \%.

Більшість медиків знала ( $\mathrm{n=112}$ - 91,1 \%), що будьякий СК необхідно негайно видалити, як тільки потреба в ньому відпала, проте інші питання стосовно строків видалення та заміни СК викликали труднощі у респондентів. Так, 17,9 \% респондентів $(n=22)$ допускали, що щоденна заміна перифреричних СК дозволить знизити ризик розвитку інфрекційних ускладнень катетеризації судин у дорослих пацієнтів. Інші 21,1 \% МП (n=26) зазначили, що їм важко відповісти на вказане питання. Частка опитаних, які знали що рутинна заміна ЦВК та катетерів для гемодіалізу не є ефективним заходом запобігання КАІК, склала 38,2 \% (n=47) та 21,1 \% (n=26) відповідно. Дещо більше респондентів ( $\mathrm{n}=50$ з $\mathrm{n}_{\text {валідее }}=122$ - 41,0 \%) знали, що регулярну заміну периферично імплантованих ЦВК недоцільно застосовувати для запобігання КАІК. Дві третини опитаних МП (n=79 з $\mathrm{n}_{\text {валідне }}=$ 121 - 65,3 \%) не знали строків заміни приладдя для іноузії у пацієнтів, яким не проводять вливання крові, її компонентів і жирових емульсій.

На недостатню обізнаність деяких респондентів 3 питань використання антибактерійних препаратів для профрілактики інфекційних ускладнень катетеризації судин вказує те, що тільки дві третини опитаних ( $\mathrm{n}=78$ - 63,4 \%) знало про відсутність потреби у проведенні рутинної системної антибіотикопрофрілактики перед введенням ЦВК з метою запобігання колонізації катетера мікроорганізмами та/або розвитку KAIK.

При аналізі питань третього блоку встановлено, що 99,2 \% МП (n=122) вважали, що перед будь-якою маніпуляцією із СК необхідно обов'язково проводити гігієнічну обробку рук. Один респондент зазначив (0,8 \%), що в екстрених випадках, коли важлива кожна секунда, цією процедурою можна нехтувати. Частка МП, які погодились з необхідністю проведення гігієнічної обробки рук після маніпуляцій із СК, також склала 99,2 \% ( $\mathrm{n=121}$ $\left.3 \mathrm{n}_{\text {валідне }}=122\right)$, однак один опитаний $(0,8 \%)$ вважав, що в цьому випадку проводити гігієнічну обробку рук недоцільно. Більшість респондентів вважала, що для гігіє-

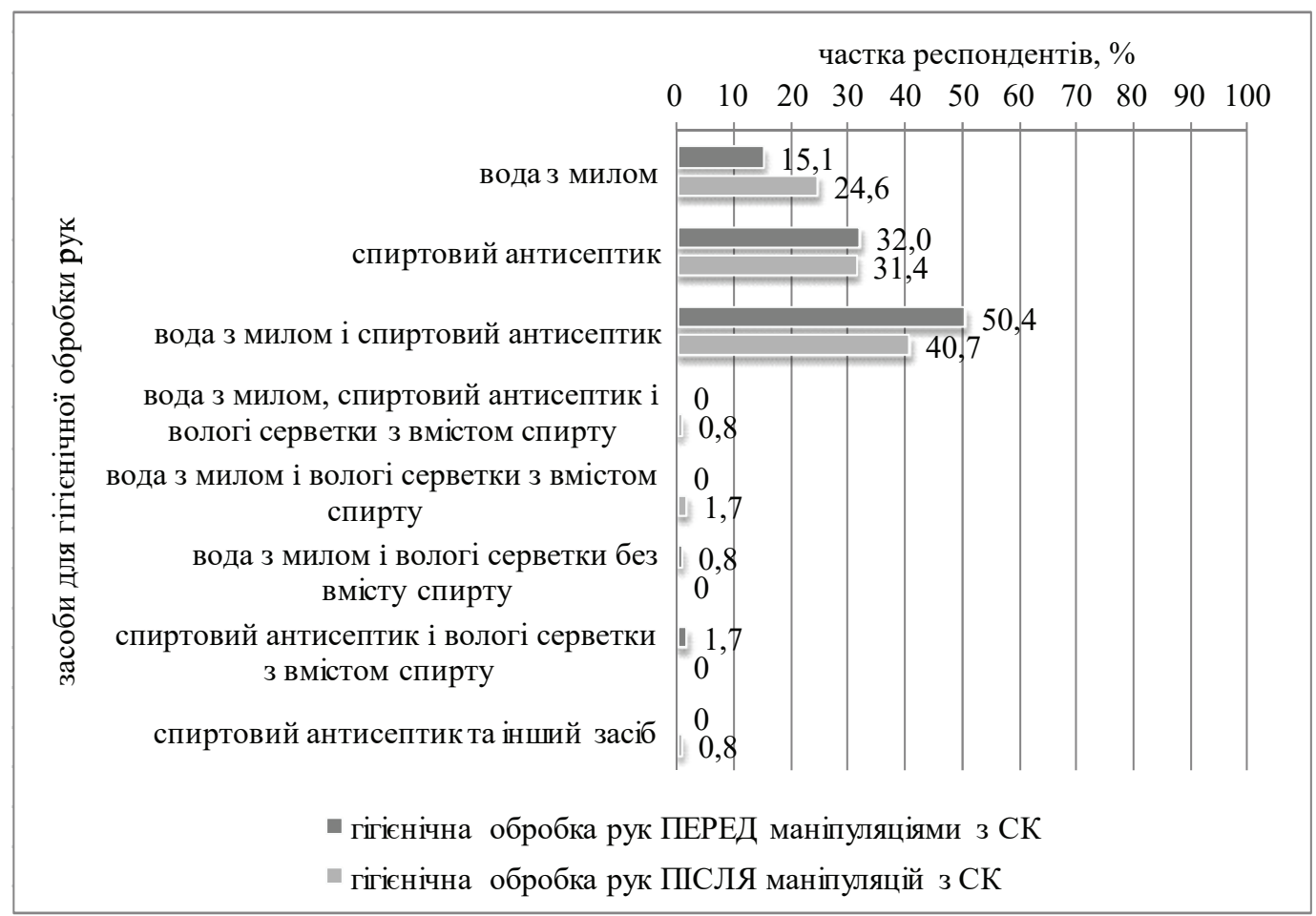

Мал. 5. Розподіл відповідей респондентів щодо засобів, які необхідно використовувати при гігієнічній обробці рук перед (n=119) та після (n=118) маніпуляцій із СК. 
нічної обробки рук при роботі із СК необхідно застосовувати воду з милом та спиртовий антисептик. Розгорнутий аналіз відповідей представлено на малюнку 5.

Всі респонденти ( $\mathrm{n}_{\text {валідне }}=121-100,0 \%$ ) погодились, що при маніпуляціях із СК $є$ необхідність у використанні рукавичок. Більшість МП ( $\mathrm{n}=1193 \mathrm{n}_{\text {валідне }}=121$ - 97,5\%) підтвердила, що у рутинній практиці завжди користується рукавичками під час маніпуляцій із СК. Здебільшого, це нестерильні чисті (n=53 зі 121 - 43,8 \%) та стерильні (n=44 зі 121 - 36,4,8 \%) рукавички. Інші респонденти вказали, що користуються і стерильними, і нестерильними чистими рукавичками (n=13 зі 121 - 10,7 \%), нестерильними рукавичками, що повторно використовуються після обробки антисептиком ( $\mathrm{n}=6$ зі $121-5,0$ \%), а також нестерильними чистими та нестерильними рукавичками, що повторно використовуються після обробки антисептиком ( $n=5$ зі $121-4,1 \%)$. Гігієнічну обробку рук спиртовим антисептиком перед використання рукавичок завжди виконує тільки 88,1 \% опитаних (n=104 з $\left.\mathrm{n}_{\text {валідне }}=118\right)$, в деяких випадках $-3,4 \%$ опитаних ( $\mathrm{n}=4$ зі 118). Деяка кількість МП ( $n=143 \mathrm{n}_{\text {валідне }}=121$ - 11,6 \%) допускає, що використання рукавичок може замінити гігієнічну обробку рук при роботі із СК.

При уточненні, в яких конкретно випадках при роботі із СК респонденти використовують рукавички, встановлено, що більшість опитаних (n=104 $3 \mathrm{n}_{\text {валідне }}=121$ 86,0 \%) використовує рукавички при будь-якій маніпуляції із СК. Частка МП, які користуються рукавичками при постановці перифреричного СК, склала 12,4 \% (n=15 зі 121), при проведенні інфузій - 9,9 \% (n=12 зі 121), при видаленні СК - 9,1 \% (n=11 зі 121), при промиванні СК - 3,3 \% (n=4 зі 121), при зміні пов'язки, що фріксує СК $1,7 \%(n=2$ зі 121).

Незважаючи на те, що 97,5 \% респондентів вказали, що завжди користуються рукавичками при роботі із СК, при аналізі їх подальших відповідей встановлено ряд причин, які перешкоджають постійному застосуванню рукавичок у практичній діяльності. Це недостатня забезпеченість медичного персоналу рукавичками (n=19 3 $\mathrm{n}_{\text {валідне }}=64-29,7 \%$ ), заміна рукавичок процедурою гігієнічної обробки рук ( $n=16$ із $64-25,0 \%)$, виникнення алергічних реакцій та/або контактного дерматиту в результаті застосування рукавичок ( $n=13$ із $64-20,3 \%)$, а також брак часу ( $\mathrm{n=12}$ із $64-18,8$ \%). Три респонденти (3,7 \%) вказали, що рукавички заважають проведенню медичних маніпуляцій, а ще один МП (1,6 \%) вказав, що вважає використання рукавичок при маніпуляціях із СК недоцільним. Між тим, 26,6 \% опитаних ( $n=17$ із 64) ще раз наголосили, що завжди використовують рукавички при роботі із СК.

Учасникам опитування було запропоновано обрати засіб для фріксації СК, якому, на їх думку, необхідно віддавати перевагу та вказати, який спосіб фріксації СК здебільшого вони змушені використовувати на практиці. Виявилось, що незважаючи на те, що більшість медиків віддає перевагу прозорій напівпроникній пов'язці ( $n=55$ $\left.3 \mathrm{n}_{\text {валідне }}=122-45,1 \%\right)$, вони змушені фріксувати СК лейкопластиром непрозорим ( $n=60$ зі $122-49,2 \%)$, який може перешкоджати проведенню ефективного моніторингу за станом місця катетеризації.

\section{Висновки}

Виявлено недостатній рівень знань, прихильності та практики МП $з$ питань епідеміології, інфекційного контролю та профрілактики інфекційних ускладнень катетеризації судин. Це вірогідно пов'язано з відсутністю нормативного підґрунтя для епідеміологічного нагляду та профілактики інфекційних ускладнень процедури катетеризації, зокрема КАІК. Проте, навіть при наявності наказів 3 питань внутрішньолікарняних інфекцій та обробки рук, відповіді респондентів вказують на недоліки у професійній підготовці та прогалини в знаннях. Для підвищення рівня знань МП щодо питань роботи із СК та профрілактики інфекційних ускладнень процедури катетеризації судин, в закладах охорони здоров'я необхідно розробляти та впроваджувати програми з інфекційного контролю, які будуть включати регулярні тренінги для медичного персоналу, розробку та оновлення локальних протоколів, алгоритмів і стандартних операційних процедур. Крім того, необхідно забезпечити персонал достатньою кількістю засобів індивідуального захисту та антисептичних засобів. 


\section{Література}

1. European Centre for Disease Prevention and Control. Healthcare-associated infections acquired in intensive care units - Annual epidemiological report for 2017 / ECDC. - Stockholm, 2019. - P. 1. URL : https://www.ecdc.europa.eu/sites/default/ files/documents/AER_for_2017-HAl.pdf (date of the application: 12.07.2020)

2. Health care workers' knowledge and practices regarding the prevention of central venous catheter-related infection / S. Alkubati, N. Ahmed, O. Mohamed [et al.] // American Journal of Infection Control. - 2015. - Vol. 43 (1). - P. 26-30. DOI: 10.1016/j.ajic.2014.09.021.

3. The reduction of risk in central line-associated bloodstream infections: Knowledge, attitudes, and evidence-based practices in health care workers / A. Bianco, P. Coscarelli, C. Nobile [et al.] // American Journal of Infection Control. - 2013. - Vol. 41 (2). - P. 107112. DOI: 10.1016/j.ajic.2012.02.038.

4. Kurian R. N. A study to assess the knowledge of staff nurses regarding central line associated blood stream infection (CLABSI) with a view to develop information-booklet on prevention of CLABSI in a selected hospital of Delhi / R. N. Kurian, N. John // International Journal of Nursing and Midwifery Research. - 2016. - Vol. 3 (2\&3). - P. 17-20.

5. «Опитувальник «Використання внутрішньосудинних катетерів у клінічній практиці»/ Чумаченко Т.О., Бережна А.В. // Свідоцтво про реєстрацію авторського права на твір № 84621 від 21.01.2019.

\section{References}

1. European Centre for Disease Prevention and Control. (2019). Healthcare-associated infections in intensive care units. Annual Epidemiological Report for 2017. Stockholm. Retrieved from: https:// www.ecdc.europa.eu/sites/default/files/documents/AER_for_2017HAl.pdf.

2. Alkubati, S., Ahmed, N., Mohamed, O., Fayed, A., \& Asfour, H. (2015). Health care workers' knowledge and practices regarding the prevention of central venous catheter-related infection. American Journal of Infection Control, 43 (1), 26-30. DOI: 10.1016/j. ajic.2014.09.021.

3. Bianco, A., Coscarelli, P., Nobile, C., Pileggi, C., \& Pavia, M. (2013). The reduction of risk in central line-associated bloodstream infections: Knowledge, attitudes, and evidence-based practices in health care workers. American Journal of Infection Control, 41 (2), 107-112. DOI: 10.1016/j.ajic.2012.02.038.

4. Kurian, R.N., \& John, N. (2016). A study to assess the knowledge of staff nurses regarding central line associated blood stream infection (CLABSI) with a view to develop information-booklet on prevention of CLABSI in a selected hospital of Delhi. International Journal of Nursing and Midwifery Research, 3 (2\&3), 17-20.

5. Chumachenko, T., Berezhna, A. (2019). Copyright certificate. Ukraine. Questionnaire «Using of intravascular catheters in clinical practice». 84621 [in Ukrainian].

\section{EVALUATION OF THE LEVEL OF KNOWLEDGE, ATTITUDES AND PRACTICE OF HEALTHCARE WORKERS REGARDING WORK WITH VASCULAR CATHETERS AND THE PREVENTION OF INFECTIOUS COMPLICATIONS OF VASCULAR CATHETERIZATION}

\author{
A.V. Berezhna, S.D. Novikov, T.O. Chumachenko \\ Kharkiv National Medical University
}

SUMMARY. The aim of the study was to evaluate the knowledge, attitudes and practice (KAP) of healthcare workers (HCW) regarding vascular catheterization (VC) and the prevention of infectious VC complications.

Materials and methods. A cross-sectional study was conducted among $123 \mathrm{HCW}$ of healthcare settings in Ukraine in September-November 2019 and January 2020 using the author's questionnaire. The questionnaire contained three blocks and 48 questions. Microsoft Excel
2007 and Epi Info Epi Info ${ }^{\mathrm{TM}}$ for Windows version 7.2 were used for statistical analysis of the data. The significance level for $\chi^{2}$-test was set at $P<0.05$.

Results and discussion. The most of respondents (78.3\%) noted the need for more facts about possible VC complications, and $79.3 \%$ of them required for additional data on infection control and prevention (ICP) of catheter-associated infections. A statistically significant association between the need to obtain extra information about the VC complications and the respondents' position was established: $X^{2}=7.9758$, $p=0.004741$.

Insufficient knowledge of risk groups and factors were identified in HCW. $31.1 \%$ of them believed that HCW had small impact on infectious VC complications occurrences. $33.4 \%$ of HCW knew about inexpediency of routine replacement of central venous catheters (CVCs), peripheral inserted CVCs, and hemodialysis catheters. 


\section{ОРИГІНАЛЬНІ ДОСЛІДЖЕННЯ}

99.2\% of HCW considered that before and after any $V C$ it is necessary to perform hand hygiene $(\mathrm{HH})$ using a soap and water or alcohol based hand rubs. In routine practice, $97.5 \%$ of HCW always used gloves with VC. $11.6 \%$ of HCW considered that gloving can replace $\mathrm{HH}$ with VC.

HCW neglected the use of gloves with VC because insufficient gloves provision (29.7\%). The quarter of respondents (25.0\%) replaced gloves with $\mathrm{HH}$. Due to allergic reactions or contact dermatitis as a result of the gloves usage, $20.3 \%$ of HCW refused to use its.

Conclusions. An insufficient level of KAP of HCW on epidemiology, ICP of infectious VC complications was determined.

Key words: cross-sectional study; catheter-related bloodstream infections; infection control; hand hygiene.

\section{Відомості про авторів:}

Бережна Антоніна Валентинівна - аспірант кафедри епідеміології Харківського національного медичного університету; e-mail: a.v.berezhna@gmail.com

Новіков Станіслав Дмитрович - студент Харківського національного медичного університету; e-mail: nsd.071098@ gmail.com

Чумаченко Тетяна Олександрівна - д. мед. н., професор, завідувач кафредри епідеміології Харківського національного медичного університету; e-mail: tatalchum@gmail. com

\section{Information about the authors:}

Berezhna A. V. - PhD student of the Department of Epidemiology, Kharkiv National Medical University; e-mail: a.v.berezhna@gmail.com

Novikov S. D. - student, Kharkiv National Medical University e-mail: e-mail: nsd.071098@gmail.com

Chumachenko T. O. - MD, Professor, Head of the Department of Epidemiology, Kharkiv National Medical University; e-mail: tatalchum@gmail.com

Консрлікт інтересів: немає.

Authors have no conflict of interest to declare.

Отримано 1.09.2020 p. 